\title{
Myers-Briggs Type Indicator (Mbti) Personality and Career Indecision among Malaysian Undergraduate Students of Different Academic Majors
}

\author{
Lee Wai Kin*, Mohd Rustam Mohd Rameli \\ School of Education, Universiti Teknologi Malaysia, Malaysia \\ Received January 22, 2020; Revised April 1, 2020; Accepted April 21, 2020
}

Copyright $\mathrm{C} 2020$ by authors, all rights reserved. Authors agree that this article remains permanently open access under the terms of the Creative Commons Attribution License 4.0 International License

\begin{abstract}
Due to the exam oriented Malaysian education system coupled with societal preconceived notions of a supposedly ideal career, Malaysian undergraduates lack the opportunity for career exploration, resulting in career indecision. Therefore, clearer understanding of their own personality can potentially guide Malaysian undergraduates in analyzing their own strengths and weaknesses as well as in processing career information and environment, which in turn helps in their career decision making. As such, the purpose of this study is to investigate the link between MBTI personality type, academic major and career indecision among Malaysian undergraduates, since such studies in the Malaysian context are lacking in current literature. A quantitative research design was employed and the respondents comprised of 500 sophomore (Year 2 and Year 3) undergraduate students from six different academic majors (Engineering, Science, Architecture, Education, Human Resources and Computing) in Universiti Teknologi Malaysia, obtained via stratified random sampling. Myers-Briggs Type Indicator (MBTI) and Career Decision Difficulties Questionnaire (CDDQ) were used as the instruments in this study. Descriptive and inferential statistics were used to analyzed the results of this study. Chi-Square Test revealed significant association between academic major and two MBTI personality constructs. ANOVA demonstrated significant differences between means for career decision when comparing Engineering-Education undergraduates as well as Engineering-Computing undergraduates. The study has demonstrated to some extent, the association between MBTI personality and academic major, in which the findings can be potentially applied to optimize one's performance in a selected major, in turn reducing career indecision.
\end{abstract}

Keywords Myers-Briggs Personality Type, Career Indecision, Academic Major, Malaysian Undergraduate Students

\section{Background of Study}

Due to the lack of exposure to various real-life vocational information and experience at high school education phase among young Malaysians, there is a considerable possibility that Malaysian undergraduate students make decisions of their majors in their tertiary education without proper justification. This results in career indecision, the inability in choosing desired university major or vocation as they move on towards the work realm ${ }^{1}$.

Malaysian students mainly make such decisions based on assumptions and societal expectations because of the struggle in identifying their real interests ${ }^{20}$. This vocational cluelessness can also be attributed to the Malaysian secondary and pre-university education system whereby the subjects taken by students are largely determined by the schools' prescription ${ }^{9,12}$, rather than the actual domains that students want to explore. Brown ${ }^{2}$ reported that a large number of college students showed indecisiveness in selecting initial vocational preferences.

Counselling research reported by Herr, Cramer and Niles portrayed that more than $50 \%$ of university students encounter career-related problems such as career maturity, career readiness, career self-efficacy and career exploration, ultimately resulting in career indecision ${ }^{8}$. Apart from this, there are many occupational categories and industries that remained alien to Malaysian graduates nowadays ${ }^{4}$, thus lowering their chances in obtaining a desirable career. 


\subsection{Problem Statement}

Theoretically, final year undergraduates aged 21-23 should have undergone career crystallization and specification of career option ${ }^{11}$, whereby they form self-concept to match their interest and work-related abilities. In fact, Ramlee and Maimun as well as Makki, Salleh, Memon and Harun, stated that career exploration is necessary for youth to gain opportunity in making connection between academic and practical subjects with work-related skills, starting at secondary school level. ${ }^{10,14}$

However, due to the rigidity of the Malaysian education system coupled with resultant societal perception of a 'good career', ${ }^{13}$, Malaysian students lack the opportunity for career exploration in the attempt to match their own personal attributes such as personality, interests, skills and values with real-life occupational demands in the market ${ }^{11}$. Reece ${ }^{15}$ reported that career undecidedness is positively correlated to stress, implying the effects of career indecision to one's psychological well-being. There are several studies on the relationship between career indecision and personality, using the Five Factor Model. However, there is a lack of empirical studies that links career indecision with personality based on the Myers-Briggs Type Indicator (MBTI), especially in the Malaysian context among different academic majors.

\subsection{Objectives}

The objectives of this study are as follows:

1. To study the most prevalent MBTI personality type among UTM undergraduate students of different academic majors.

2. To study the career indecision level of UTM undergraduate students across different academic majors.
3. To investigate the association between MBTI type and academic major of UTM undergraduate students.

4. To investigate the differences of career indecision across academic major of UTM undergraduate students.

\section{Methodology}

A cross-sectional quantitative research design was utilized to fulfil the objectives of this study. This study focuses on the population of sophomore undergraduate students (second or third year of study) in Universiti Teknologi Malaysia (UTM) from six Schools under different academic majors (Mechanical Engineering, Science, Architecture, Education, Human Resource and Computing). A total of 500 sophomore undergraduate students were sampled via stratified random sampling based on the six selected Schools in UTM.

The instruments used for this study were Myers-Briggs Type Indicator (MBTI) adapted from $\mathrm{Chang}^{3}$ as well as Career Decision-Making Difficulties Questionnaire (CDDQ) developed by Gati, Krausz, and Osipow ${ }^{5}$. Objectives 1 and 2 were analyzed using descriptive statistics while the analysis for Objectives 3 and 4 were in form of inferential statistics (Chi-Square Test and ANOVA respectively).

\section{Findings}

Table 1 illustrated the descriptive analysis for MBTI personality types of sophomore undergraduates in UTM across six different academic majors. 
Myers-Briggs Type Indicator (Mbti) Personality and Career Indecision among Malaysian Undergraduate Students of Different Academic Majors

Table 1. Frequency and Percentage of MBTI Personality Types Based on Academic Major

\begin{tabular}{|c|c|c|c|c|c|c|c|c|}
\hline \multirow{3}{*}{ Academic Major } & \multicolumn{8}{|c|}{ MBTI Personality Dichotomy } \\
\hline & \multicolumn{2}{|c|}{ Direction of Energy Flow } & \multicolumn{2}{|c|}{ Perceptions of the World } & \multicolumn{2}{|c|}{ Decision-Making Style } & \multicolumn{2}{|c|}{ Life Structure } \\
\hline & $\begin{array}{c}\mathbf{E} \\
\mathbf{f} \\
(\%)\end{array}$ & $\begin{array}{c}\text { I } \\
\mathbf{f} \\
(\%)\end{array}$ & $\begin{array}{c}S \\
\mathbf{f} \\
(\%)\end{array}$ & $\begin{array}{c}\mathbf{N} \\
\mathbf{f} \\
(\%)\end{array}$ & $\begin{array}{c}\mathbf{T} \\
\mathbf{f} \\
(\%)\end{array}$ & $\begin{array}{c}\mathbf{F} \\
\mathbf{f} \\
(\%)\end{array}$ & $\begin{array}{c}\mathbf{J} \\
\mathbf{f} \\
(\%)\end{array}$ & $\begin{array}{c}\mathbf{P} \\
\mathbf{f} \\
(\%) \\
\end{array}$ \\
\hline \multirow{2}{*}{ Engineering } & 66 & 59 & 82 & 43 & 88 & 37 & 80 & 45 \\
\hline & $(52.80)$ & $(47.20)$ & $(65.60)$ & $(34.40)$ & $(70.40)$ & $(29.60)$ & $(64.00)$ & $(36.00)$ \\
\hline \multirow{2}{*}{ Science } & 49 & 46 & 65 & 30 & 67 & 28 & 68 & 27 \\
\hline & $(51.58)$ & $(48.42)$ & $(68.42)$ & $(31.58)$ & $(70.53)$ & $(29.47)$ & $(71.58)$ & $(28.42)$ \\
\hline \multirow{2}{*}{ Architecture } & 37 & 29 & 26 & 40 & 33 & 33 & 38 & 28 \\
\hline & $(56.06)$ & $(43.94)$ & $(39.39)$ & $(60.61)$ & $(50.00)$ & $(50.00)$ & $(57.58)$ & $(42.42)$ \\
\hline \multirow{2}{*}{ Education } & 50 & 11 & 43 & 18 & 41 & 20 & 31 & 30 \\
\hline & $(81.97)$ & $(18.03)$ & $(70.49)$ & $(29.51)$ & $(67.21)$ & $(32.79)$ & $(50.82)$ & (49.18) \\
\hline \multirow{2}{*}{ Human Resource } & 44 & 24 & 51 & 17 & 41 & 27 & 46 & 22 \\
\hline & $(64.71)$ & $(35.29)$ & $(75.00)$ & $(25.00)$ & $(60.29)$ & $(39.71)$ & $(67.65)$ & $(32.35)$ \\
\hline \multirow{2}{*}{ Computing } & 46 & 39 & 57 & 28 & 56 & 29 & 51 & 34 \\
\hline & $(54.12)$ & $(45.88)$ & $(67.06)$ & $(32.94)$ & $(65.88)$ & $(34.12)$ & $(60.00)$ & $(40.00)$ \\
\hline \multirow{2}{*}{ Overall } & 287 & 205 & 317 & 175 & 320 & 172 & 307 & 185 \\
\hline & (58.33) & (41.67) & (64.43) & (35.57) & $(65.04)$ & (34.96) & $(62.40)$ & (37.60) \\
\hline
\end{tabular}

$\mathrm{E}=$ Extrovert, $\mathrm{I}=$ Introvert, $\mathrm{S}=$ Sensing, $\mathrm{N}=$ Intuitive, $\mathrm{T}=$ Thinking, $\mathrm{F}=$ Feeling, $\mathrm{J}=$ Judging, $\mathrm{P}=$ Perceiving $(\mathrm{f}=$ frequency)

Table 2. Frequency and Percentage of Career Indecision Levels Based on Academic Major

\begin{tabular}{|c|c|c|c|c|c|c|c|c|c|}
\hline \multirow{3}{*}{ Academic Major } & \multicolumn{9}{|c|}{ Career Indecision } \\
\hline & \multicolumn{3}{|c|}{ Lack of Readiness } & \multicolumn{3}{|c|}{ Lack of Information } & \multicolumn{3}{|c|}{ Inconsistent Information } \\
\hline & $\begin{array}{c}\text { Low } \\
\text { f } \\
(\%)\end{array}$ & $\begin{array}{c}\text { Mod } \\
\text { f } \\
(\%)\end{array}$ & $\begin{array}{c}\text { High } \\
\text { f } \\
(\%)\end{array}$ & $\begin{array}{c}\text { Low } \\
\text { f } \\
(\%)\end{array}$ & $\begin{array}{c}\text { Mod } \\
\text { f } \\
(\%)\end{array}$ & $\begin{array}{c}\text { High } \\
\text { f } \\
(\%)\end{array}$ & $\begin{array}{c}\text { Low } \\
\text { f } \\
(\%)\end{array}$ & $\begin{array}{c}\text { Mod } \\
\text { f } \\
(\%)\end{array}$ & $\begin{array}{c}\text { High } \\
\text { f } \\
(\%)\end{array}$ \\
\hline \multirow{2}{*}{ Engineering } & 13 & 85 & 27 & 12 & 71 & 42 & 19 & 79 & 27 \\
\hline & $(10.40)$ & $(68.00)$ & $(21.60)$ & $(9.60)$ & $(56.80)$ & $(33.60)$ & $(15.20)$ & $(63.20)$ & $(21.60)$ \\
\hline \multirow{2}{*}{ Science } & 8 & 70 & 17 & 9 & 53 & 33 & 17 & 66 & 12 \\
\hline & $(8.42)$ & $(73.68)$ & $(17.89)$ & $(9.47)$ & $(55.79)$ & $(34.74)$ & (17.89) & $(69.47)$ & (12.63) \\
\hline \multirow{2}{*}{ Architecture } & 8 & 38 & 20 & 9 & 32 & 25 & 10 & 41 & 15 \\
\hline & (12.12) & $(57.58)$ & $(30.30)$ & (13.64) & $(48.48)$ & $(37.88)$ & $(15.15)$ & $(62.12)$ & $(22.73)$ \\
\hline \multirow{2}{*}{ Education } & 13 & 35 & 13 & 24 & 23 & 14 & 18 & 31 & 12 \\
\hline & (21.31) & (57.38) & $(21.31)$ & (39.34) & (37.70) & $(22.95)$ & $(29.51)$ & $(50.82)$ & (19.67) \\
\hline \multirow{2}{*}{ Human Resource } & 8 & 47 & 13 & 13 & 35 & 20 & 11 & 43 & 14 \\
\hline & (11.76) & (69.12) & (19.12) & (19.12) & (51.47) & $(29.41)$ & (16.18) & $(63.24)$ & (20.59) \\
\hline \multirow{2}{*}{ Computing } & 13 & 64 & 8 & 24 & 44 & 17 & 21 & 61 & 3 \\
\hline & (15.29) & (75.29) & $(9.41)$ & (28.24) & (51.76) & (20.00) & (24.71) & (71.76) & $(3.53)$ \\
\hline \multirow{2}{*}{ Overall } & 63 & 339 & 98 & 91 & 258 & 151 & 96 & 321 & 83 \\
\hline & (12.60) & $(67.80)$ & (19.60) & (18.20) & (51.60) & $(30.20)$ & (19.20) & (64.20) & (16.60) \\
\hline
\end{tabular}

*Level of Career Indecision: Individual Mean Score of 1.00-2.33=Low; 2.34-3.67=Moderate; 3.68-5.00=High (f= frequency) 
Table 3. Mean, Standard Deviation and Level of Career Indecision Based on Academic Major

\begin{tabular}{|c|c|c|c|c|c|}
\hline \multirow[b]{2}{*}{ Academic Major } & \multicolumn{5}{|c|}{ Career Indecision } \\
\hline & $\begin{array}{c}\text { Lack of Readiness } \\
\text { M } \\
\text { (SD) } \\
\end{array}$ & $\begin{array}{c}\text { Lack of Information } \\
\mathrm{M} \\
\text { (SD) } \\
\end{array}$ & $\begin{array}{c}\text { Inconsistent Information } \\
\mathrm{M} \\
\text { (SD) } \\
\end{array}$ & $\begin{array}{c}\text { Overall } \\
\text { M } \\
\text { (SD) } \\
\end{array}$ & Level \\
\hline \multirow{2}{*}{ Engineering } & 3.24 & 3.46 & 3.12 & 3.26 & \multirow{2}{*}{ Moderate } \\
\hline & $(0.25)$ & $(0.07)$ & $(0.24)$ & $(0.24)$ & \\
\hline \multirow{2}{*}{ Science } & 3.17 & 3.20 & 3.34 & 2.99 & \multirow{2}{*}{ Moderate } \\
\hline & $(0.37)$ & $(0.45)$ & $(0.14)$ & $(0.34)$ & \\
\hline \multirow{2}{*}{ Architecture } & 3.24 & 3.31 & 3.21 & 3.25 & \multirow{2}{*}{ Moderate } \\
\hline & $(0.26)$ & $(0.12)$ & $(0.19)$ & $(0.21)$ & \\
\hline \multirow{2}{*}{ Education } & 3.05 & 2.78 & 2.85 & 2.92 & \multirow{2}{*}{ Moderate } \\
\hline & $(0.43)$ & $(0.09)$ & $(0.17)$ & $(0.32)$ & \\
\hline \multirow{2}{*}{ Human Resource } & 3.15 & 3.18 & 3.10 & 3.14 & \multirow{2}{*}{ Moderate } \\
\hline & $(0.34)$ & $(0.09)$ & $(0.17)$ & $(0.25)$ & \\
\hline \multirow{2}{*}{ Computing } & 3.01 & 3.01 & 2.74 & 2.93 & \multirow{2}{*}{ Moderate } \\
\hline & $(0.39)$ & $(0.11)$ & $(0.42)$ & $(0.36)$ & \\
\hline \multirow{2}{*}{ Overall } & 3.16 & 3.22 & 3.00 & 3.13 & \multirow{2}{*}{ Moderate } \\
\hline & $(0.31)$ & $(0.07)$ & $(0.25)$ & $(0.26)$ & \\
\hline
\end{tabular}

*Level of Career Indecision: Group Mean Score of 1.00-2.33=Low; 2.34-3.67=Moderate; 3.68-5.00=High ( $M=$ Mean, SD = Standard Deviation)

Based on Table 1, the most prevalent MBTI type for each academic major were respectively Thinking for Engineering major, Judging for Science major, Intuitive for Architecture major, Extraversion for Education Major as well as Sensing for Human Resources and Computing major. Based on Table 2, undergraduates who scored high in the construct of lack of information of career indecision was higher compared to the other two constructs. Table 3 showed that the undergraduates from the major of Engineering and Architecture obtained the first and second highest mean for overall career indecision. Meanwhile, the two majors with the lowest mean were Education and Computing.

Table 4. Chi-Square Tests (Direction of Energy Flow X Academic Major)

\begin{tabular}{|c|c|c|c|}
\hline & Value & $\mathrm{df}$ & $\begin{array}{c}\text { Asymp. Sig. } \\
(2 \text {-sided })\end{array}$ \\
\hline Pearson Chi-Square & $19.282^{\mathrm{a}}$ & 5 & .002 \\
\hline Likelihood Ratio & 20.821 & 5 & .001 \\
\hline $\begin{array}{c}\text { Linear-by-Linear } \\
\text { Association }\end{array}$ & 2.600 & 1 & .107 \\
\hline N of Valid Cases & 500 & & \\
\hline
\end{tabular}

a. 0 cells $(0.0 \%)$ have expected count less than 5 . The minimum expected count is 25.38 .

According to Table 4, Chi-Square test showed significant association between academic major and Direction of Energy Flow (MBTI construct), $\chi^{2}(5, \mathrm{~N}=500$ ) $=19.28, \mathrm{p}=.002, \phi=0.196$. Based on Table 5, there was also significant association between academic major and Perception of the World (MBTI construct), $\chi^{2}(5, \mathrm{~N}=500)=$ $23.42, \mathrm{p}=.000, \phi=0.216$.

Table 5. Chi-Square Tests (Perception of the World X Academic Major)

\begin{tabular}{|c|c|c|c|}
\hline & Value & $\mathrm{df}$ & $\begin{array}{c}\text { Asymp. Sig. } \\
(2 \text {-sided })\end{array}$ \\
\hline Pearson Chi-Square & $23.416^{\mathrm{a}}$ & 5 & .000 \\
\hline Likelihood Ratio & 22.538 & 5 & .000 \\
\hline $\begin{array}{c}\text { Linear-by-Linear } \\
\text { Association }\end{array}$ & .817 & 1 & .366 \\
\hline N of Valid Cases & 500 & & \\
\hline
\end{tabular}

a. 0 cells $(0.0 \%)$ have expected count less than 5 . The minimum expected count is 21.47 .

Table 6. ANOVA (Career Indecision X Academic Major)

\begin{tabular}{|c|c|c|c|c|c|}
\hline & $\begin{array}{c}\text { Sum of } \\
\text { Squares }\end{array}$ & df & $\begin{array}{c}\text { Mean } \\
\text { Square }\end{array}$ & F & Sig. \\
\hline $\begin{array}{c}\text { Between } \\
\text { Groups }\end{array}$ & 9.638 & 5 & 1.928 & 4.133 & .001 \\
\hline Within Groups & 230.386 & 494 & .466 & & \\
\hline Total & 240.024 & 499 & & & \\
\hline
\end{tabular}

Table 7. Robust Tests of Equality of Means (Career Indecision X Academic Major)

\begin{tabular}{|c|c|c|c|c|}
\hline & Statistic $^{\mathrm{a}}$ & $\mathrm{df1}$ & $\mathrm{df2}$ & Sig. \\
\hline Welch & 4.272 & 5 & 207.097 & .001 \\
\hline Brown-Forsythe & 3.907 & 5 & 384.013 & .002 \\
\hline
\end{tabular}

a. Asymptotically F distributed. 
Table 8. Post Hoc Tests (Tukey HSD)

\begin{tabular}{|c|c|c|c|c|c|c|}
\hline \multicolumn{9}{|c|}{ Dependent Variable: Career Indecision } \\
\hline \multirow{3}{*}{ (I) Major } & (J) Major & $\begin{array}{c}\text { Mean Difference } \\
(\mathrm{I}-\mathrm{J})\end{array}$ & Std. Error & \multirow{2}{*}{ Sig. } & \multicolumn{2}{c|}{$95 \%$ Confidence Interval } \\
\cline { 3 - 7 } & Science & .09402 & .09295 & .914 & -.1719 & .3600 \\
\hline \multirow{3}{*}{ Engineering } & Architecture & .02318 & .10391 & 1.000 & -.2741 & .3205 \\
\cline { 2 - 7 } & Education & $.35249^{*}$ & .10666 & .013 & .0473 & .6576 \\
\cline { 2 - 8 } & Human Resource & .12148 & .10290 & .846 & -.1729 & .4159 \\
\cline { 2 - 8 } & Computing & $.33736^{*}$ & .09601 & .006 & .0627 & .6120 \\
\hline
\end{tabular}

As shown in Table 6 and Table 7 respectively, Classic ANOVA $[\mathrm{F}(5,494)=4.133, \mathrm{p}=.001]$ and Welch's ANOVA $[F(5,207.097)=4.272, p=.001]$ showed that there was significant difference between career indecision and academic major. Thus, Tukey post hoc test was computed as referred to Table 8 , indicating significant differences of mean score of career indecision between undergraduates from engineering and education major, as well as between undergraduates from engineering and computing major.

\section{Discussion}

Based on Table 1, the most prevalent MBTI function for Engineering major was the Thinking under the dichotomy of Decision-Making Style, in which can be explained as the nature of engineering profession which requires much critical thinking and problem-solving skills in constructing effective mechanical models which are feasible for actual application $^{7}$. Rosati $^{16}$ reported that graduates with I_TJ MBTI profile dominate the engineering major. Judging function under the dichotomy of Life Structure was the most prevalent for undergraduates in Science major. This could be attributed to methodical and systematic nature of scientific experiments, whereby Science undergraduates needs to be organized and rule-abiding to minimize error in their laboratory works. Ware ${ }^{21}$ reported the high prevalence of Judging (92\%) type function among pharmacy students. Rottinghaus, Lindley, Green and Borgen reported that conscientiousness, which corresponds to the Judging type is associated to good planning and organizational skills ${ }^{17}$.

The Intuitive function tend to be highly prevalent among Architecture undergraduates, as being creative and having abundant of ideas could be advantageous in producing ground breaking architectural designs. Most undergraduates from the Education Major tend to be extroverts, which could be a pre-requisite or catalyst to be effective in implementation instructional strategies as well as interaction with students, as supported by Rottinghaus, Lindley, Green and Borgen ${ }^{17}$. For both human resources and computing major, the most prevalent MBTI type was Sensing. This can be elucidated due to the fact that the tasks in both fields require high level of attention to detail, and are of less need for the in-depth interpretation of the meaning behind the tasks.

With reference to the Chi Square analysis, there was a considerable association between two MBTI dichotomies $(\mathrm{E} / \mathrm{I} \& \mathrm{~S} / \mathrm{N})$ and academic decision. This means that for the case of direction of energy flow (E/I) and perception of the world $(\mathrm{S} / \mathrm{N})$, the selection of an academic major that is compatible with one's MBTI typing can potentially facilitate their learning and adaptability in that discipline, which in turn boost the chances of excelling in careers of corresponding field.

Based on Table 2, the endorsement of high score for CDDDQ occurred most under the construct of Lack of Information compared to the other two constructs. This implies that students had a harder time obtaining career-related information, either about their own abilities and personality or about the characteristics of a particular occupation. This can be supported by the fact that the Malaysian education system may have placed too much emphasis on examination and academic $\operatorname{grades}^{19}$. Therefore, there is a lack of priority to promote self-development or career exploration programs at school and university levels, in order to provide a better channel for students to obtain information on their potentials as well as prospective career options ${ }^{12}$.

Based on comparison of means and ANOVA, career indecision of undergraduates from Engineering were significantly higher than undergraduates from Education and Computing. This could be attributed to the more technical nature and vocational environment of Engineering field, which may require certain predispositions and skillsets in order to cope and excel in. Rouvrais and Chelin elaborated that some engineering students are not career-driven and do not actually aim to be engineers $^{18}$.

Another explanation is that the preconceived notion on the status and expected salaries for Engineers and Architects. Survey conducted by Gibson and Hutton reported that $79 \%$ of the respondents viewed engineering field with high respect based on moderate familiarity, while $82 \%$ respondents viewed engineering as financially rewarding ${ }^{6}$. Such perception may lead some students to choose in Engineering major based on external factors rather than their innate suitability in those majors. On the 
other hand, it may be easier to identify interest towards the field of education or computing due to the more direct exposure to role models in school as well as the emergence of $4^{\text {th }}$ industrial revolution respectively.

\section{Conclusions}

The present study has exhibited the concerning issues of career indecision among Malaysian undergraduate students. The study has also demonstrated some degree of association between MBTI personality and academic major, which can potentially optimize one's performance in a selected major and in turn reduce career indecision. Therefore, the relationship between MBTI personality and career indecision as well as its mediating and moderating factors, can be further examined, in order to improve the application of MBTI to facilitate the real-world solution for career-related dilemmas or difficulties.

\section{Conflict of Interest}

Nil

\section{Source of Funding}

Fundamental Research Grant Scheme (Vot. No. RJI30000.7853.5F039).

\section{Ethical Clearance}

Obtained from Ministry of Education Malaysia

\section{REFERENCES}

[1] Borgen W, Hiebert B. Career guidance and counselling for youth: What adolescents and young adults are telling us. International Journal for the Advancement of Counselling. 2006 Dec 1;28(4):389-400.

[2] Brown SD, Hacker J, Abrams M, Carr A, Rector C, Lamp K, Telander K, Siena A. Validation of a four-factor model of career indecision. Journal of Career Assessment. 2012 Feb;20(1):3-21.

[3] Chang DS. Myers Briggs Type Indicator (MBTI) Personality Test. 2012 [Cited 2 December 2019]. Available from https://artofthinkingsmart.com/what-is-your-personality-ty $\mathrm{pe} /$

[4] Forstenlechner I, Selim H, Baruch Y, Madi M. Career exploration and perceived employability within an emerging economy context. Human Resource Management. 2014 Jan;53(1):45-66.

[5] Gati I, Krausz M, Osipow SH. A taxonomy of difficulties in career decision making. Journal of counseling psychology.
1996 Oct;43(4):510.

[6] Gibson B, Hutton R. Public perceptions of engineers \& engineering. (2017) [Cited 2 December 2019]. Available from Engineers Canada website: https://engineerscanada.ca/reports/public-perceptions

[7] Hassan B, Mohd Zaidi O, Zainal M, Abang Abdullah AA, Badrulhisham AA, Abdul Hamid H, Nik Abdullah NM, Azmi H, Zaidi MR. The future of engineering education in Malaysia. Report by the Department of Institutions of Higher Education Management, Ministry of Higher Education, Malaysia; 2007.

[8] Herr E, Cramer S, Niles S. Career guidance and counseling through lifespan: Systematic approaches. Boston: Little, Brown; 2004.

[9] Lee MN. Education in Malaysia: towards vision 2020. School effectiveness and school improvement. 1999 Mar 1;10(1):86-98.

[10] Makki BI, Salleh R, Memon MA, Harun H. The relationship between work readiness skills, career self-efficacy and career exploration among engineering graduates: A proposed framework. Research Journal of Applied Sciences, Engineering and Technology. 2015 Jul 25;10(9):1007-11.

[11] Mansor AT, Tan KA. Influence of gender on career readiness among Malaysian undergraduates. Australian Journal of Career Development. 2009 Jul;18(2):33-44.

[12] Marzuki S. Isu pendidikan di Malaysia: Sorotan dan cabaran. Kuala Lumpur: Utusan Publications \& Distributors; 1999.

[13] Osipow SH. Assessing career indecision. Journal of Vocational behavior. 1999 Aug 1;55(1):147-54.

[14] Ramlee M, Maimun AL. Diverse learners in vocational and technical education. Education for Diverse Learners. Serdang, Selangor: Universiti Putra Press; 2009.

[15] Reece EJ. Stress and career indecision: A comparison of senior athletes and non-athletes (Unpublished master's thesis). Texas State University, San Marcos, Texas; 2011.

[16] Rosati P. Academic progress of Canadian engineering students in terms of MBTI personality type. International Journal of Engineering Education. 1998 Jan 1;14(5):322-7.

[17] Rottinghaus PJ, Lindley LD, Green MA, Borgen FH. Educational aspirations: The contribution of personality, self-efficacy, and interests. Journal of Vocational Behavior. 2002 Aug 1;61(1):1-9.

[18] Rouvrais S, Chelin N. Engineer Professional Identity: For an early clarification of student's perceptions. In Electronic Proceedings of the 6th International CDIO Conference, École Polytechnique, Montréal; 2010

[19] Suffean Hussin. Pendidikan di Malaysia: Sejarah, sistem, dan falsafah. Kuala Lumpur: Dewan Bahasa dan Pustaka; 2004.

[20] Tak J, Lee KH. Development of the Korean career indecision inventory. Journal of Career Assessment. 2003 Aug;11(3):328-45.

[21] Ware KB. Relationships Between Myers-Briggs Type Indicators and NAPLEX Performances. American Journal of Pharmaceutical Education. 2019 Feb 1;83(1). 